CASE REPORT

\title{
Ibuprofen and acute renal failure in a toddler
}

\author{
N E Moghal, S Hegde, K M Eastham
}

Arch Dis Child 2004;89:276-277. doi: 10.1136/adc.2002.024141

long buprofen and paracetamol are equally effective ${ }^{1}$ and widely used antipyretic agents in paediatric practice. There is no evidence to support the concept that treating a fever with antipyretics, paracetamol, or ibuprofen, will prevent febrile convulsions. ${ }^{2}$ Ibuprofen is available over the counter and is used in addition to or instead of paracetamol both in hospital and community settings. It is advertised on television. There is an increasing trend to routinely prescribe both drugs for children specifically to manage fever. Although it is considered to be a reasonably safe drug, ${ }^{3}$ there are reports of nephrotoxicity, ${ }^{4}$ including renal failure when ibuprofen is administered to volume depleted children. ${ }^{6}$

\section{CASE REPORT}

A previously well, 18 month old, $10.5 \mathrm{~kg}$ boy presented with a four week history of intermittent cough and wheeze. In the week prior to admission he developed a fever, increasing lethargy, anorexia, and refusing to drink adequately. His fever was initially treated with paracetamol (5 ml (120 mg) up to four times a day), but with a persisting fever ibuprofen was then given in addition over the subsequent week at the correct dose (2.5 $\mathrm{ml}$ (50 mg), maximum six doses), until three days prior to admission, during which time he was noted to have increasingly dry nappies. On examination he was afebrile, sleepy but rousable, mildly dehydrated, with normal capillary refill and normal blood pressure $(90 \mathrm{~mm} \mathrm{Hg}$ systolic). He was mildly tachypnoeic (38 breaths/min) with scattered expiratory wheeze. Urinalysis showed 2+ protein, $1+$ glucose, and no blood. Phase contrast microscopy revealed one mixed cellular cast but no cells or organisms. He was profoundly hyperkalaemic (potassium $8.7 \mathrm{mmol} / \mathrm{l}$ ), acidotic (bicarbonate $12 \mathrm{mmol} / \mathrm{l}$ ), and uraemic (urea $69.6 \mathrm{mmol} / \mathrm{l}$, creatinine $523 \mu \mathrm{mol} / \mathrm{l}$ ). Blood glucose was $9.2 \mathrm{mmol} / \mathrm{l}$ with subsequent normal values. A full blood count and film was normal except for a raised white cell count $\left(21.6 \times 10^{9} / 1\right)$ with a predominant neutrophilia. C3 and C4 complement levels and an autoantibody profile were normal. A nasopharyngeal aspirate ultimately confirmed a respiratory syncytial virus infection to account for his cough and wheeze.

Following appropriate emergency management of the hyperkalaemia, peritoneal dialysis was commenced and continued for six days. An ultrasound scan 12 hours after admission showed large ( $>95$ th centile) echogenic kidneys with reduced corticomedullary differentiation but no obstruction.

A renal biopsy was done four days after admission. The 17 glomeruli identified were all normal. There was marked interstitial oedema. The tubules showed marked epithelial attenuation with nuclear pleomorphism and mitotic activity, in keeping with extensive acute tubular necrosis. The blood vessels were normal. Immunofluoresence was negative for immune proteins.

One year follow up has revealed a slightly depressed glomerular filtration rate at $75 \mathrm{ml} / \mathrm{min} / 1.73 \mathrm{~m}^{2}$ (Schwarz formula). A DMSA scan was normal but an ultrasound scan showed localised cortical loss in the left kidney. This suggests that the renal ischaemia was sufficient to cause a mild degree of cortical necrosis. He is currently normotensive.

\section{DISCUSSION}

Non-steroidal anti-inflammatory agents, including ibuprofen, reduce the renal synthesis of prostaglandins by inhibiting the enzyme cyclooxygenase. In a euvolaemic state prostaglandins have a negligible effect on renal haemodynamics. Where there is ineffective circulating plasma volume, there is an upregulation of the renin-angiotensin system as well as increased catecholamine release, which in addition to producing renal vasoconstriction also stimulates renal prostaglandin production. These prostaglandins counteract the vasoconstrictor effect by decreasing the pre-glomerular resistance and thereby maintain renal perfusion and glomerular filtration. This protective effect is inhibited by the administration of ibuprofen, resulting in unopposed renal vasoconstriction, leading to renal failure. Animal data suggest that the immature kidney is particularly vulnerable to these effects. ${ }^{7}$

Young children with pyrexia are at an increased risk of dehydration as they may be unwilling or unable to drink, may not have access to water, and have an increased insensible loss due to relatively greater body surface area. Milder degrees of dehydration can be difficult to detect in these children or may go unnoticed, at home, under primary care supervision, or even in an inpatient setting. Clinical states change and a child who is initially only febrile may later have additional losses such as diarrhoea and vomiting. Prescribing ibuprofen where there is, or there is the potential for, volume depletion is therefore not without risk.

The patient information sheet for ibuprofen lacks advice on the importance of maintaining good fluid intake and hydration when taking ibuprofen and makes no mention of the rare but serious side effect of acute renal failure. We would recommend that ibuprofen be avoided in infants and toddlers for the management of pyrexia where the child is dehydrated or could potentially become dehydrated during the course of an illness. Paracetamol is an effective antipyretic agent when used in adequate doses.

\section{Authors' affiliations \\ N E Moghal, S Hegde, Department of Paediatric Nephrology, Royal \\ Victoria Infirmary, Newcastle upon Tyne NE1 4LP, UK \\ K M Eastham, Department of Child Health, Royal Victoria Infirmary, Newcastle upon Tyne NE1 4LP, UK \\ Competing interests: none}

Correspondence to: $\operatorname{Dr} N$ E Moghal, Consultant Paediatric Nephrologist, Department of Paediatric Nephrology, Royal Victoria Infirmary, Newcastle upon Tyne NE1 4LP, UK; n.e.moghal@nd.ac.uk

Accepted 12 July 2003

\section{REFERENCES}

1 Mclntyre J, Hull D. Comparing efficacy and tolerability of ibuprofen in fever. Arch Dis Child 1996;74:164-7. 
2 Philips B. Archimedes. Do antipyretics prevent febrile convulsions? Report by El-Radhi AS, Barry W. Arch Dis Child 2003;88:638-42.

3 Lesko SM, Mitchell AA. An assessment of the safety of pediatric ibuprofen. JAMA 1995;273:929-33.

4 Mann JFE, Goering M, Brune K, et al. Ibuprofen as an over-the-counter drug: is there a risk for renal injury? Clin Nephrol 1993;39:1-6.
5 Murray MD Brater DC, Tierney WM et al Ibuprofen-associated renal impairment in a large general internal medicine practice. Am J Med Sci 1990;229:222-9

6 Moghal NE, Hulton SA, Milford DV. Care in the use of ibuprofen as an antipyretic in children. Clin Nephrol 1998:49:293-5.

7 Drukker A, Mosig D, Guinard J. The renal hemodynamic effects of aspirin in newborn and young adult rabbits. Pediatr Nephrol 2001;16:713-18.

\section{IMAGES IN PAEDIATRICS}

\section{When is an abnormal frenulum a sign of child abuse?}

A

5 year old child was referred to the child protection team following recurrent presentations to A\&E with vaginal discharge and concerns of maternal neglect. She was put on the child protection register and placed with her father. At review she was well, but examination revealed a small tag along the lower edge of the frenulum and a gap between her incisors. There were no subsequent concerns, and she was referred to the University Dental Institute. The tagged appearance of the frenulum was thought to have arisen congenitally although traumatic injury could not be excluded. An aunt and uncle also had similar frenula and a diagnosis of a midline diastema of developmental origin was made. She was followed up with a view to orthodontic space closure and frenectomy.

It is frequently stressed that a "torn frenulum" may be evidence of physical abuse following a direct blow or forcing objects into the mouth, ${ }^{1}$ but alternative explanations should not be overlooked. An abnormal frenulum may be associated with midline defects, sinuses, and hypoplastic left heart syndrome. ${ }^{2}{ }^{3}$ With concerns of abuse and neglect the cause of an abnormal frenulum can be difficult to diagnose. Dentists may see oral injuries from abuse and neglect such as tooth fractures, lacerations, palatal lesions, fractures, and multiple caries. Their role should not be overlooked ${ }^{4-7}$ and in this case they helped to differentiate a "torn frenulum" from a congenital abnormality.

L Chan, D Hodes Greenland Road Children's Centre, 4 Greenland Road, London NW1 OAS, UK; deborah.hodes@cichs-tr.nthames.nhs.uk doi: 10.1136/adc. 2003.031534

\section{References}

1 Meadows R. ABC of child abuse, 3rd edn. London: BMJ Books, 1997.

2 Lovell MA, McDaniel NL. Association of hypertrophic maxillary frenulum with hypoplastic left heart syndrome. J Pediatr 1995;127:749-50.

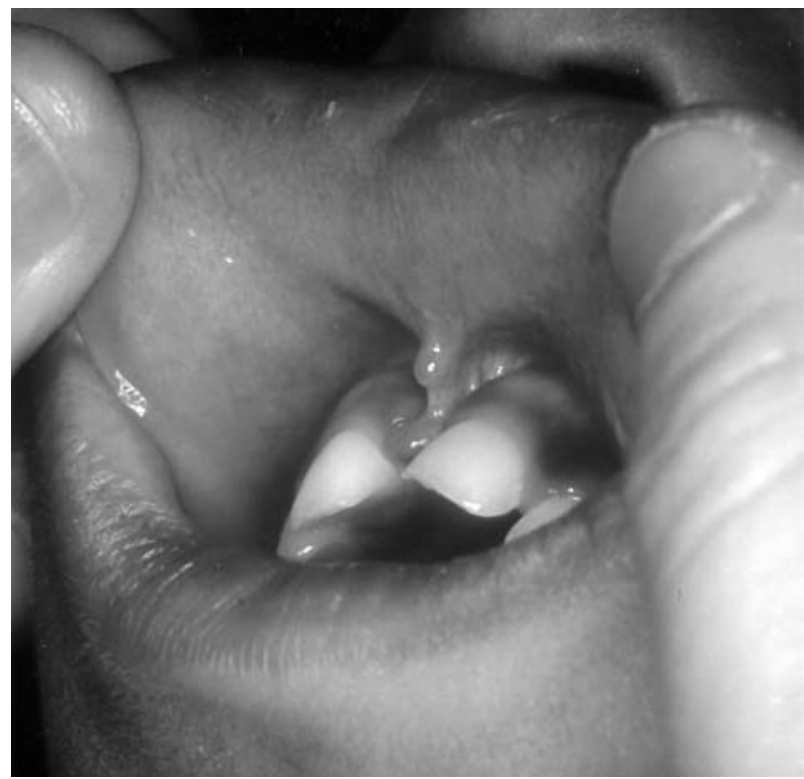

3 Asahina I, Sakakibara T, Miyashin M, et al. Congenital midline sinus of the upper lip: case report and review of literature. Cleft Palate Craniofac J 1997;34:83-5.

4 Department of Health. Working together to safeguard children. A guide to inter-agency working to safeguard and promote the welfare of children. London: The Stationary Office, 1999.

5 Da Fonseca MA, Feigal RJ, ten Bensel RW. Dental aspects of 1248 cases of child maltreatment on file at a major county hospital. Pediatr Dent 1992;14:152-7.

6 Spencer DE. Recognising and reporting child abuse. J Calif Dent Assoc 1996;24:43-9.

7 Von Burg MM, Hibbard RA. Child abuse education: do not overlook dental professionals. ASDC J Dent Child 1995;62:57-63. 